\title{
Financial Integration and Common Currency Area in ASEAN
}

\author{
Behrooz Gharleghi, Najla Shafighi, and Benjamin Chan Yin Fah
}

\begin{abstract}
As ASEAN economies moved to closer economic integration in recent years, exchange rate arrangement become an important regional concern especially after the currency crisis of 1997-98. This paper used the Augmented Dickey-Fuller and Phillips-Perron unit root tests with Johansen-Juselius cointegration approach to find out whether there is any cointegration among ASEAN countries' exchange rates. Data are collected from 1985 M01 to 2010 M09 and divided into two groups of pre-crisis (Jan 1985 to Dec 1996) and post-crisis (Jan 1999 to sep 2010). The result reveals that there is a unique cointegrating vector in post-crisis period only, suggesting a long-run equilibrium relationship between ASEAN exchange rates. Obtained results have important implications for developing a common currency area.
\end{abstract}

Index Terms-Cointegration, exchange rate, unit root, VECM.

\section{INTRODUCTION}

The push towards greater integration within regional trading blocs has shifted into high gear in recent years. If the launch of Euro currency can be regarded as a success, then it can be used as a model for Association of South East Asian Nations (ASEAN), namely; Indonesia, Malaysia, Philippine, Singapore and Thailand to prevent the repeat of the 1997 financial crisis. The main and ultimate goal of forming an economic union is to create a common currency area. Therefore, in this research, the possibility of forming a single currency examined within South East Asia countries.

Integration is a difficult process and there will invariably be setbacks and crises. Nevertheless, in the European Union (EU) case, the Cassandras are nearly always proven wrong. The EU has an excellent record of recovering from crises and moving ahead even stronger than before due to firm political will. While there has been some unfavorable media attention in Euro zone, but governments and other regional bodies have retained faith in the union.

Since one of the concerns of the governments of South East Asian countries is to introduce a currency union in the region, it has been an issue for past decades especially after 1997 financial crisis. For this purpose, the question of the present paper is to identify whether ASEAN countries can

Manuscript received September 2, 2013; revised November 5, 2013.This work was supported in part by the Ministry of Higher Education in Malaysia under Fundamental Research Grant Scheme. The authors would like to gratefully acknowledge the financial support from Ministry of Higher Education (MOHE) Malaysia, FRGS scheme.

Behrooz Gharleghi and Benjamin Chan Yin Fah are with the Asia Pacific University of Technology an Innovation, Bukit Jalil, 57000, Malaysia (e-mail: behrooz@apu.edu.my, benjamin@apu.edu.my).

Najla Shafighi is with the National University of Malaysia, 43600, Bangi, Malaysia (e-mail: Shafighi_nab@yahoo.com). undergo into a currency union or not.

Before 1997, few people would have seriously advocated monetary cooperation in East Asia especially the ASEAN Countries. But the financial crisis of 1997 in East Asia provided costly lessons for the East Asian Countries in the importance of regional cooperation [1]. The crisis fundamentally changed East Asia's perspective on economic integration and be the cause of a great political interest in monetary and financial cooperation in the region. The crisis revealed the financial fragility of the region and highlighted the need for a regional financial architecture. Since 1997 crisis, there has been a proliferation of proposal to fostering ASEAN monetary and financial integration.

In November 1999, leaders of the ASEAN agreed to create the establishment of currency swaps and repurchase agreements as a credit line against future financial shocks. In May 2000, the finance minister of the ASEAN agreed through the "Chiang Mai Initiative" to plan for closer monetary and financial cooperation [2]. In November 2002, it was proposed at the ASEAN Heads of Government meeting in Phnom Penh that the region should consider the possibility of creating an ASEAN Economy Community (AEC) by 2020, a timeframe that was later shortened to 2015. In May 2005, ASEAN Members have agreed to expand their network of bilateral currency swaps into multi-lateralization, which could eventually create a "de facto Asian Monetary Fund". Another key issue has been taken up is forging the Asian Bond Market Initiative (ABMI) by ensuring that Asia collects more of its own saving for channeling into local investment instead of relying on borrowing from outside the region [1]. Therefore, these steps are now widely envisioned to provide a significant basis for regional monetary integration with the possible formation of a single common currency.

It has been suspected that the 1997 financial crisis in Asia may have affected the financial integration in these countries. Therefore, the data analysis divided into two sample periods, pre-crisis and post-crisis in order to detect the possible differences in financial integration pattern.

\section{PREVIOUS STUdies}

Several authors applied the convergence of exchange rates in different countries to identify the financial integration.

Sato, Zhang and Allen [3] employed the Johansen cointegration approach to investigate the long-run co-movement of real outputs in East Asia, USA and Japan to find some implications for forming a monetary union. Their results suggest that some NIEs of Asian countries plus the USA is a potential for monetary union. Furthermore, ASEAN countries with inclusion of Japan can be a feasible group for 
forming a monetary union which has important implication for the role of Japan.

Azali and Chin [4] applied the Johansen-Juselius cointegration approach to check whether there is any cointegration among ASEAN+3 exchange rates in three time period of pre-crisis, crisis and post-crisis. They found that there is a unique cointegrating vector during the crisis and post-crisis periods.

Huang \& Guo [1] employed a four-variable structural VAR model to make an assessment of the viability of creating an OCA in East Asia. There results showed that the 1997 financial crisis may help ASEAN countries to improve the correlation of supply shocks in the region. The findings also support that Japan has a leading role in capital markets in East Asia. Their finding confirmed Bayuomi and Eichengreen [5] that argued whole of this region do not have enough readiness to form an OCA. They proposed that Korea, Hong Kong, Indonesia, Malaysia, Singapore and Thailand create a currency union firstly.

Zhang, Sato and McAleer [6] focused on the shocking aspect (only internal shocks) of monetary union. They analyzed the feasibility of "Grater China" (Chinese trio: Taiwan, Hong Kong, and Mainland China) to move towards a currency union. They employed a three-variable VAR model including real effective exchange rate (demand shock), money supply (monetary shock), and real output (supply shock). Results showed that increasing the symmetry of shocks among Great China make it possible for Chinese trio to create a currency union.

Baharumshah and Goh [7] pointed out the relationship of exchange rates between Japan and some East Asian countries (Indonesia, Malaysia, Philippine, Singapore, Korea, Taiwan and Thailand) from 1978 to 1998 to investigate whether events that took place in 1990s (rise of UD dollar, the Mexico tequila crisis...) has affected these financial markets. They found that the Philippine Peso and Korean Won do not belong to the cointegration relationship.

Aggarawal and Mougoue [8] examined the cointegration of exchange rates between Japanese yen with two set of Asian countries; first set of Hong Kong, Korea, Singapore and Taiwan. Second set comprises of Malaysia, Philippine, Thailand and Singapore using daily data from 1983 to 1992. A structural break on Oct 1987 that crash the stock market was detected and so analysis conducted in two sub-periods. Both sets are found to be cointegrated. Besides, they also examined the influence of Japanese yen and USD in both sets and found that influence of Japanese yen in both sets has increased relative to USD.

\section{METHODOLOGY}

If there are more than two variables then, Johansen-Juselius cointegration methodology [9] must be implemented, because there may be more than one cointegration vector. Johansen-Juselius cointegration technique represents the same thing as a multivariate generalization of the Dickey-Fuller used for unit root test [10].

Instead of y representing a single variable, there is an $x$ and $\varepsilon$ representing $(n \times 1)$ vectors, $A$ denotes $(n \times n)$ matrix and $I$ is $(n \times n)$ identity matrix.

$$
\begin{aligned}
\Delta x_{t} & =\pi x_{t-1}+\varepsilon_{t} \\
\pi_{t} & =\left(A_{t}-I\right)
\end{aligned}
$$

The rank of $\pi$ matrix $r$ represents the number of linear combination of variables included in $\pi$ matrix or number of cointegrating vectors. The following is the two tests statistics which declare the rank of matrix:

$$
\begin{aligned}
& \lambda_{\text {trace }}(r)=-T \sum_{i=r+1}^{n} \ln \left(1-\hat{\lambda}_{i}\right) \\
& \lambda_{\text {max }}(r, r+1)=-T \ln \left(1-\hat{\lambda}_{r+1}\right)
\end{aligned}
$$

where

$\hat{\lambda}_{i}$ is the estimated value of the characteristic roots obtained from the estimated $\pi$ matrix and $T$ is the number of usable observation.

\section{DATA AND EMPIRICAL RESULTS}

The data set consists of the monthly exchange rate for five ASEAN countries covering the period of Jan 1985 to Sep 2010. This timeframe is selected because it is covering the financial crisis in East Asia. The time period is divided into two groups, first is from Jan 1985 to Dec 1996 and second is from Jan 1999 to Sep 2010, therefore data from Jan 1997 until Dec 1998 has been removed and it is not reflected in the analysis. The exchange rates are Indonesian rupiah (IDR), Malaysian Ringgit (MYR), Singapore Dollar (SGD), Philippines Peso (PHP) and Thailand Baht (THB) against USD.

TABLE I: ADF UNIT ROOT TEST PRE-CRISIS

\begin{tabular}{lllll}
\hline $\begin{array}{l}\text { Exchange } \\
\text { Rate }\end{array}$ & \multicolumn{2}{c}{ Level } & \multicolumn{2}{c}{ First Difference } \\
\hline IDR & Constant & with Trend & Constant & with Trend \\
MYR & -2.00 & -2.38 & $-11.92^{*}$ & $-11.99^{*}$ \\
PHP & -2.15 & -2.15 & $-11.29^{*}$ & $-11.25^{*}$ \\
SGD & -1.72 & -1.83 & $-13.20^{*}$ & $-13.25^{*}$ \\
THB & -0.53 & -2.98 & $-12.48^{*}$ & $-12.44^{*}$ \\
\hline \hline
\end{tabular}

* Significant at $1 \%$

TABLE II: PHILLIPS-PERRON UNIT ROOT TEST PRE-CRISIS

\begin{tabular}{lllll}
\hline $\begin{array}{l}\text { Exchange } \\
\text { Rate }\end{array}$ & \multicolumn{2}{c}{ Level } & \multicolumn{2}{c}{ First Difference } \\
\hline & Constant & with Trend & Constant & with Trend \\
IDR & -2.02 & -2.39 & $-11.92^{*}$ & $-12.00^{*}$ \\
MYR & -2.37 & -2.37 & $-11.29 *$ & $-11.26^{*}$ \\
PHP & -1.72 & -1.91 & $-13.14^{*}$ & $-13.19^{*}$ \\
SGD & -0.29 & -2.51 & $-12.46^{*}$ & $-12.42^{*}$ \\
THB & -2.05 & -2.93 & $-14.00^{*}$ & $-14.38^{*}$ \\
\hline \hline
\end{tabular}

* Significant at $1 \%$

The order of integration of all exchange rate series determined using Phillips-Peron (PP) and Augmented Dickey -Fuller (ADF) unit root tests. The results of two unit root test in following tables clearly indicate that the null of 
unit root test cannot be rejected at 5\% level for all exchange rates at their levels. But null hypothesis is rejected when first-difference of above mentioned currencies is considered, so all currencies are integrated of order one. (See Table ITable IV)

TABLE III: ADF UNIT ROOT TEST POST-CRISIS

\begin{tabular}{|c|c|c|c|c|}
\hline Exchange & \multicolumn{2}{|c|}{ Level } & \multicolumn{2}{|c|}{ First Difference } \\
\hline & Constant & with Trend & $\begin{array}{l}\text { Constan } \\
\mathrm{t}\end{array}$ & with Trend \\
\hline IDR & -2.14 & -3.16 & -11.72 & -11.68 \\
\hline MYR & 0.52 & -2.10 & -9.94 & -10.06 \\
\hline PHP & -1.85 & -1.65 & -10.36 & -10.80 \\
\hline SGD & 0.52 & -2.08 & -11.62 & -11.78 \\
\hline THB & 0.01 & -2.15 & -10.43 & -10.70 \\
\hline
\end{tabular}

* Significant at $1 \%$

TABLE IV: PHILLIPS-PERRON UNIT ROOT TEST POST-CRISIS

\begin{tabular}{lllll}
\hline $\begin{array}{l}\text { Exchange } \\
\text { Rate }\end{array}$ & \multicolumn{2}{c}{ Level } & \multicolumn{2}{c}{ First Difference } \\
\hline & Constant & with Trend & Constan & with Trend \\
IDR & -2.23 & -3.08 & $-11.83^{*}$ & $-11.79 *$ \\
MYR & 0.31 & -2.29 & $-9.94^{*}$ & $-10.07^{*}$ \\
PHP & -1.92 & -1.65 & $-10.45^{*}$ & $-10.80^{*}$ \\
SGD & 0.51 & -2.09 & $-11.62^{*}$ & $-11.78^{*}$ \\
THB & 0.12 & -2.24 & $-10.42^{*}$ & $-10.72^{*}$ \\
\hline \hline
\end{tabular}

* Significant at $1 \%$

Since all series are of same order (order one), we can proceed to check the cointegrating relations among variables using Johansen-Juselius cointegration test [11]. Table $\mathrm{V}$ and Table VI reports the results and indicate that the null of no cointegrating vector cannot be rejected for pre-crisis period. But it is rejected in post-crisis period. This implies that above mentioned currencies are not cointegrated in the pre-crisis period and cointegrated with one cointegrating vector in the post-crisis period.

TABLE V: JOHANSEN-JUSELIUS COINTEGRATION TEST PRE-CRISIS

\begin{tabular}{ccccc}
\hline & Trace & 5\% Critical Value & Max-Eigen & $\begin{array}{c}5 \% \text { Critical } \\
\text { Value }\end{array}$ \\
\hline $\mathrm{r}=0$ & 68.20 & 68.52 & 29.81 & 33.46 \\
$\mathrm{r} \leq 1$ & 38.39 & 47.21 & 19.34 & 27.07 \\
$\mathrm{r} \leq 2$ & 19.04 & 29.68 & 13.15 & 20.97 \\
$\mathrm{r} \leq 3$ & 5.89 & 15.41 & 3.89 & 14.07 \\
$\mathrm{r} \leq 4$ & 1.99 & 3.76 & 1.99 & 3.76 \\
\hline \hline$*$ Significant at 5\% & & &
\end{tabular}

** Significant at 5\%

TABLE VI: JOHANSEN-JUSELIUS COINTEGRATION TEST POST-CRISIS

\begin{tabular}{ccccc}
\hline & Trace & 5\% Critical Value & Max-Eigen & $\begin{array}{c}5 \% \text { Critical } \\
\text { Value }\end{array}$ \\
\hline $\mathrm{r}=0$ & $70.1 * *$ & 68.52 & $34.52 * *$ & 33.46 \\
$\mathrm{r} \leq 1$ & 35.65 & 47.21 & 16.29 & 27.07 \\
$\mathrm{r} \leq 2$ & 19.35 & 29.68 & 12.13 & 20.97 \\
$\mathrm{r} \leq 3$ & 7.21 & 15.41 & 7.20 & 14.07 \\
$\mathrm{r} \leq 4$ & 0.00 & 3.76 & 0.00 & 3.76 \\
\hline \hline
\end{tabular}

** Significant at $5 \%$

Although cointegration may exist among above mentioned
ASEAN exchange rates in post-crisis period, but not all of these exchange rates will be in cointegration vector. For this issue, exclusion test has been performed by imposing zero restriction on the Beta $(\beta)$ coefficient of cointegrating vector. The result of this imposition reported in Table VII.

The Log-Likelihood ratio showed that Rupiah (IDR), Singapore Dollar (SGD) and Baht (THB) rejected the null of cointegrating parameter equal to zero in post-crisis period. This indicates that Malaysian Ringgit (MYR) and Philippine Peso (PHP) could be excluded from the system.

\begin{tabular}{cc} 
TABLE VII: EXCLUSION RESTRICTION TEST \\
\hline Exchange Rate & Likelihood Ratio \\
\hline IDR & $16.21 *$ \\
MYR & 2.27 \\
PHP & 0.07 \\
SGD & $18.22^{*}$ \\
THB & $7.24 *$ \\
\hline Significant at $1 \%$
\end{tabular}

The Johansen-Juselius cointegration test re-estimated for the remaining series after exclusion test (namely for IDR, SGD, and THB). Results are reported in Table VIII. As it can be seen from the table, both Max-Eigenvalue and test and trace test rejected the null of no cointegrating vector at $5 \%$ level of significance. These results indicate that these exchange rates are cointegrated with a unique cointegrating vector. Furthermore, the exclusion test has been done for remaining currencies and reveals that the null of cointegrating parameter equal to zero for all currencies can be rejected. Results are presented in Table IX. These findings recommend that these three currencies are bounded together by long-run relationship in post-crisis period.

TABLE VIII: JOHANSEN-JUSELIUS COINTEGRATION TEST FOR REMAINING CURRENCIES (IDR,SGD,THB)

\begin{tabular}{ccccc}
\hline & Trace & $\begin{array}{c}5 \% \text { Critical } \\
\text { Value }\end{array}$ & Max-Eigen & $\begin{array}{c}5 \% \text { Critical } \\
\text { Value }\end{array}$ \\
\hline$r=0$ & 35.36 & $29.68^{* *}$ & $25.89^{* *}$ & 20.97 \\
$r \leq 1$ & 9.47 & 15.41 & 8.35 & 14.07 \\
$r \leq 2$ & 1.11 & 3.76 & 1.11 & 3.76 \\
\hline \hline
\end{tabular}

** Significant at $5 \%$

TABLE IX: EXCLUSION RESTRICTION TEST FOR REMAINING CURRENCIES

\begin{tabular}{cc}
\hline Exchange Rate & Likelihood Ratio \\
\hline IDR & $12.28^{*}$ \\
SGD & $16.17^{*}$ \\
THB & $15.43^{*}$ \\
\hline * Significant at $1 \%$ &
\end{tabular}

* Significant at $1 \%$

\section{CONCLUSION}

As the economies of ASEAN countries becoming more integrated, this paper examined the financial integration among ASEAN currencies. To identify the differences in financial integration pattern of these countries followed by 1997 crisis, the analytical framework divided into pre-crisis and post-crisis. Presence of unit root was found for each currency in both sample periods. The result of Johansen-Juselius cointegration approach indicates no 
cointegrating vector during pre-crisis period. Cointegration relationship was identified among three currencies of IDR, SGD and THB in the post crisis period. These results implied that ASEAN countries are financially more integrated after the crisis. This finding provided weak support for regional monetary and exchange rate arrangement.

\section{REFERENCES}

[1] Y. Huang and F. Guo, "Is currency union a feasible option in East Asia? A multivariate structural VAR approach," Research in International Business and Finance, vol. 20, pp. 77-94, 2006.

[2] K. Y. Sung, "Exchange rate and monetary regime options for regional cooperation in East Asia," Journal of Asian Economics, vol. 16, pp. $57-75,2005$.

[3] K. Sato, Z. Zhang, and D. Allen, "The suitability of a monetary union in East Asia: What does the cointegration approach tell?" Mathematics and Computers in Simulation, vol. 79, pp. 2927-2937, 2009.

[4] M. Azali and L. Chin, "Asian financial integration during the pre- and post-crisis periods," Journal of International Economic Review, vol. 2 , no. 1/2, p. 103-112, 2009.

[5] T. Bayoumi and B. Eichengreen, "Shocking aspects of European monetary integration," in Adjustment and Growth in the European Monetary Union, F. Torres, F. Giavazzi (Eds.), Cambridge University Press, Cambridge, pp. 193-229, 1993.

[6] Z. Y. Zhang, S. Kiyotaka and M. Michael, "Is great China a currency union? A tail of the Chinese Trio," Mathematics and Computers in Simulation, vol. 78, pp. 319-327, 2008.

[7] A. Z. Baharumshah and W. K. Goh, "Financial integration of East Asia: Is there aYen block?" in Open Economy Macroeconomics in East Asia, ed., A. Z. Baharumshah, Ashgate: Aldershot, pp. 147-168, 2005.

[8] R. Aggarwal and M. Mougoue, "Cointegration among Asian currencies: Evidence of the increasing influence of the Japanese Yen," Japan and the World Economy, vol. 8, no. 3, pp. 291-308, 1996.

[9] S. Johansen and K. Juselius, "Maximum likelihood estimation and inference on cointegration with applications to the demand for money," Oxford Bulletin of Economics and Statistics, vol. 52, pp. 169-210, 1990.

[10] W. Enders, Applied Econometric Time Series, NJ: John Wiley and Sons, Inc., 2004.
[11] B. Gharleghi and A. H. S. M. Nor, "Is Monetary variable a determinant in the ringgit-dollar exchange rates model?" A Cointegration Approach, Sains Malaysiana, vol. 41, no. 9, pp. 1163-1169, 2012.

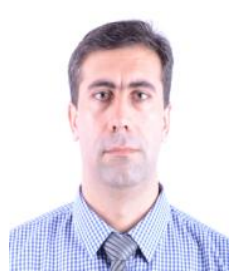

Behrooz Gharleghi is a senior lecturer at Faculty of Business and Management, Asia Pacific University of Technology and Innovation, Kuala Lumpur, Malaysia. He holds Bachelor degree (2003) and Master degree (2005) in Economics from the Islamic Azad University, Iran. He obtained his PhD from National University of Malaysia (UKM) in 2012. He has led or collaborated in two research projects funded by Ministry of Higher Education under Fundamental Research Grant Scheme. His main area of academic and research interests are financial market, exchange rate, forecasting and international trade. Behrooz Gharleghi is corresponding author and can be contacted at: gharleghi.bn@gmail.com.

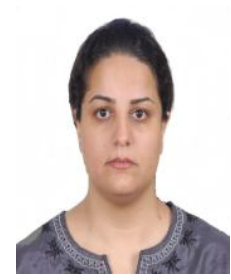

Najla Shafighi is a Ph.D candidate in Economics at Department of Economics, Faculty of Economic and Management, National University of Malaysia (UKM), Bangi, Malaysia. She obtained Bachelor degree in Economics from IAU (2004) and Master degree in Business Management form Tehran University (2009) Her main area of academic and research interests are financial market, exchange rate integration, monetary policy and forecasting.

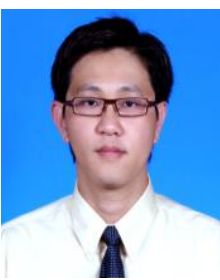

Benjamin Chan Yin Fah obtained both his bachelor and master degree in human Development and Ph.D in Gerontology from University Putra Malaysia. Having his extensive knowledge and most of his working life in academics, he has published numerous journal articles on themes related to gerontology and consumer studies. Benjamin currently is a senior lecturer in Asia Pacific University and his focus tends to switch to the area of targeting older consumer markets and how to deliver better customer value to these older population groups. 